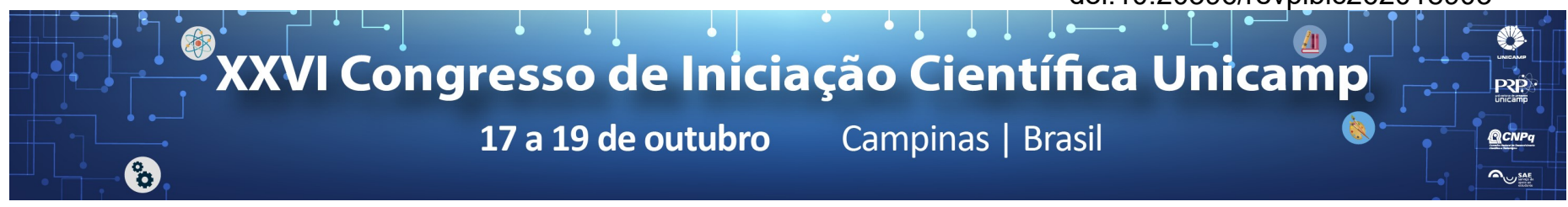

\title{
Motivos de aderência e abandono das práticas nas aulas de natação
}

\section{Lucas S. S. Moitinho, Orival Andries Junior}

\section{Resumo}

Esta pesquisa se propôs a avaliar os motivos de aderência e abandono das práticas nas aulas de natação. Os resultados foram analisados através de dois questionários sendo o primeiro de aderência e o segundo de abandono. Tal pesquisa visa contribuir e ampliar os estudos referentes a essa temática, bem como compreender os processos motivacionais e através disso manter e aumentar a adesão dos alunos nas aulas de natação.

\section{Palavras-chave:}

natação, aderência, abandono.

\section{Introdução}

Estar motivado significa ser movido para fazer alguma coisa. Uma pessoa que não sente nenhum impulso ou inspiração para agir é assim caracterizado como desmotivado, enquanto que alguém que é energizado ou ativado para um determinado fim é considerado motivado'.

Nossa pesquisa visa avaliar os motivos que causam a motivação inicial que os indivíduos apresentam ao iniciar um programa de natação e o desinteresse e abandono da prática pelos alunos, contribuindo assim para melhorar a aderência nas práticas natação, visto que fatores motivacionais podem ser grandes influenciadores na pratica de atividade física ${ }^{2}$.

\section{Resultados e Discussão}

Para realização desse estudo criamos e estruturamos dois questionários para a coleta de dados. $\mathrm{O}$ primeiro com um conteúdo direcionado para a aderência e o outro para o abandono. Foram avaliados ao todo 92 participantes pertencentes ao projeto de extensão NATação, através de entrevistas presenciais e online, sendo que destes $77 \%$ abandonaram o projeto. Para a aplicação do segundo questionário, foi adotado o mesmo critério da Universidade Estadual de Campinas sendo considerado assim abandono de projeto os alunos que obtiveram $25 \%$ de faltas.

$$
\text { Os resultados demonstram que }
$$
condicionamento físico (43\%), saúde (38\%), relaxar (11\%), emagrecimento (4\%) e aprender a nadar (4\%) são os objetivos pelos quais os alunos procuram o projeto de extensão, enquanto que provas/trabalho (58\%), saúde $(32 \%)$, clima $(26 \%)$, horário $(16 \%)$, viagens $(16 \%)$, temperatura da agua (8\%), compromissos $(8 \%)$, cansaço $(3 \%)$ e lotação da piscina (3\%) são os motivos pelos quais os alunos desistem do projeto. O presente estudo apresenta resultados semelhantes aos revelados em investigações focalizando outros programas de exercícios físicos ${ }^{3-4}$. motivação inicial e o desinteresse e abandono de determinada modalidade contribui para uma melhor aderência e continuidade da pratica, visto que fatores motivacionais podem ser grandes influenciadores na pratica de atividade física². Manter o indivíduo assíduo com a pratica de atividade física, além de adquirir todos os efeitos fisiológicos de sua pratica regular, este também apresenta uma melhoria na qualidade de vida, não apenas das capacidades físicas, mas também por questões sociais (melhoria do convívio e comportamento social) o que demonstra os efeitos positivos também no convívio social ${ }^{4}$.

\section{Conclusões}

O presente estudo teve por objetivo analisar os motivos que causam a aderência e o abandono das práticas de natação, contribuindo assim para um melhor entendimento acerca dos processos motivacionais e através disso aumentar a adesão e a manutenção do aluno nas aulas de natação.

\section{Agradecimentos}

Ao Professor Dr. Orival Andries Júnior, pelo tempo disponibilizado e pela orientação desta pesquisa.

A minha família e amigos que me apoiaram e me incentivaram para a realização desta pesquisa.

[1] RYAN, Richard M.; DECI, Edward L. Intrinsic and extrinsic motivations: Classic definitions and new directions. Contemporary educational psychology, v. 25, n. 1, p. 54-67, 2000.

[2] MURCIA, Juan Antônio Moreno; COLL, David González-Cutre. A permanência de praticantes em programas aquáticos baseada na Teoria de Autodeterminação. Fitness \& Performance Journal, n. 1, p. 5-10, 2006.

[3] RODRIGUES, Maicon. Aderência, manutenção e desistência das práticas em academia. 2018.

[4] REZENDE, Edson Campana et al. OS motivos reponsáveis pela adesâo nos projetos de extensâo em natação eo efeito da participaçâo sobre a qualidade de vida dos participantes. Coleção Pesquisa em Educação Física, v. 11, 2012. 